\title{
PENGARUH KUALITAS PELAYANAN DAN KOMITMEN MAHASISWA TERHADAP MOTIVASI BERPRESTASI MAHASISWA PERGURUAN TINGGI SWASTA
}

\author{
A. Dirwan \\ Program Magister Manajemen Universitas Suryadarma Jakarta \\ email: achmaddirwan@yahoo.co.id
}

\begin{abstract}
Abstrak: Tujan penelitian ini adalah untuk mengetahui pengaruh kualitas pelayanan dan komitmen mahasiswa terhadap motivasi berprestasi di PTS Jakarta. Subjek penelitian sebanyak 80 mahasiswa. Kerangka penelitian mengacu pada apakah kualitas pelayanan dan komitmen memunyai pengaruh terhadap motivasi berprestasi yang diukur lewat angket. Instrumen penelitian terdiri atas 25 butir pertanyaan untuk kualitas pelayanan, 26 butir komitmen, dan 29 butir motivasi berprestasi. Analisis data menggunakan teknik korelasi, analisis regresi ganda, dan koefisien jalur dengan bantuan SPSS versi 17.0. Hasil penelitian menunjukkan bahwa bahwa: (1) terdapat pengaruh dari kualitas pelayanan terhadap motivasi berprestasi; (2) terdapat pengaruh dari komitmen terhadap motivasi berprestasi; (3) terdapat pengaruh kualitas pelayanan dan komitmen secara bersama-sama terhadap motivasi berprestasi mahasiswa PTS Jakarta.
\end{abstract}

Kata Kunci: kualitas pelayanan, komitmen, motivasi berprestasi

\section{THE INFLUENCE OF SERVICE QUALITY AND STUDENT COMMITMENT ON ACHIEVEMENT MOTIVATION AT PRIVATE UNIVERSITY}

\begin{abstract}
The purpose of this study was to determine the influence of service quality and commitment on achievement motivation at Private University in Jakarta. The subject of this research were 80 students, by using 5 Likert Scale. The framework of this research was based on that service quality $\left(\mathrm{X}_{1}\right)$ and commitment $\left(\mathrm{X}_{2}\right)$ had influence of achievement motivation $(\mathrm{Y})$. The service quality was measured with 25 items question, commitment was measured with 26 items question, and achievement motivation was measured with 29 items question/statement. Data analysis used in this research was a multiple regression and path analysis. Obtained data then were examined with SPSS 17.0 version. From the research it can concluded that: (1) there was influence of service quality toward achievement motivation; (2) there was influence of commitment toward achievement motivation; (3) there was influence of service quality and commitment simultaneously toward achievement motivation students in Private University Jakarta.
\end{abstract}

Keywords : service quality, commitment, achievement motivation

\section{PENDAHULUAN}

Perkembangan lingkungan strategis yang penuh ketidakpastian merupakan tantangan yang tidak ringan bagi perjuangan bangsa Indonesia di masa depan, yang memerlukan manusia Indonesia berkualitas. Kenyataannya indeks kualitas sumber daya manusia Indonesia masih rendah. Human Development Report 2013, skor Human Development Index (HDI) menyebutkan bahwa Indonesia hanya 0,629, dengan peringkat 121 dari 187 negara. Menghadapi tantangan tersebut, dalam persaingan antarbangsa yang semakin ketat serta kemampuan untuk dapat melaksanakan agenda pembangunan bangsa, ditun- tut tersedianya sumber daya manusia berprestasi tinggi, yang didorong oleh motivasi berprestasi. Dorongan atau motivasi untuk berprestasi telah sejak lama dikenali sebagai faktor yang berpengaruh dalam belajar dan bertugas. Orang-orang yang memunyai dorongan untuk berhasil, mereka mengejar prestasi pribadi, bukan penghargaan-penghargaan dan imbalan. Seseorang yang menunjukkan kemampuan unggul dibidang intelektual biasanya memiliki dorongan kuat untuk mencapai hasil yang sempurna.

Di samping kemauan menetapkan sasaran secara realistik dan diatas rata-rata, orang yang ingin berprestasi biasanya menunjukkan 
kemampuan belajar secara berencana dan berdisiplin serta memunyai ketangguhan mengatasi rintangan. Banyak faktor yang memengaruhi motivasi berprestasi antara lain, kualitas pelayanan, kualitas dosen, kualitas pengelola, komitmen mahasiswa, dan fasilitas yang tersedia. Faktor tersebut dapat berasal dari dalam diri mahasiswa seperti komitmen ataupun dari luar dirinya seperti kualitas pelayanan.

Penelitian para ahli pada beberapa dekade terakhir menunjukkan bahwa orang yang berhasil memperoleh nilai tinggi dalam bidang akademik, ternyata selain cerdas terbukti memiliki komitmen berprestasi yang lebih. Suatu komitmen khusus yang dimiliki seseorang, menyebabkan mereka bekerja sungguh-sungguh dan tekun agar memperoleh hasil yang baik, karena kinerja seseorang secara khusus dipengaruhi oleh komitmen menyelesaikan tugasnya. Task commitment atau komitmen terhadap tugas diartikan sebagai pengikatan diri terhadap tugas sebagai bentuk motivasi internal yang mendorong seseorang untuk tekun dan ulet mengerjakan tugasnya meskipun mengalami berbagai rintangan atau hambatan. Seseorang yang memunyai komitmen dalam menyelesaikan tugas yang menjadi tanggung jawabnya, berarti telah mengikatkan dirinya terhadap tugas tersebut atas kehendaknya sendiri.

Menyongsong era Indonesia masuk dalam kelompok tujuh kekuatan ekonomi dunia pada 2030, ditargetkan mencetak 113 juta tenaga terdidik, yang saat ini hanya 55 juta (Santosa, 2014:6). Untuk itu, diperlukan perguruan tinggi (perguruan tinggi swasta jumlahnya di atas 90\%) meningkatkan kualitas, termasuk kualitas pelayanan. Dalam kamus lengkap (komprehensif) bahasa Inggris, kata kualitas memunyai banyak arti, antara lain: (1) suatu sifat atau atribut yang khas dan membuat berbeda; serta (2) memiliki standar dan sifat kebaikan tertinggi. Pelayanan perguruan tinggi swasta (PTS) dilihat dari kemampuannya memenuhi kebutuhan mahasiswa, atau kesesuaiannya dengan keinginan masyarakat pada umumnya masih terbatas. Hal ini berdasarkan kenyataan sebagian besar PTS belum terakreditasi. Padahal kualitas pelayanan PTS merupakan paduan sifat-sifat produk, yang menunjukkan kemampuannya dalam memenuhi kebutuhan mahasiswa masa kini dan masa depan.

Dalam hubungan pelayanan dan kepelayanan di atas, sumber daya manusia perguruan tinggi (PT), terutama keahlian dan keterampilan profesional, sikap dan tata etika sangat menentukan. Dengan kata lain, hubungan kemanusiaan sangat penting dan mendasar dalam industri pendidikan. PT menghasilkan jasa kependidikan, yang disajikan kepada para pelanggannya, terutama para mahasiswa. Apabila mahasiswa merasa puas atas pelayanan PT, motivasi untuk berprestasi mahasiswa meningkat.

Untuk pembuktian secara empiris fenomena di atas, perlu diadakan penelitian sejauh mana pengaruh kualitas pelayanan dan komitmen terhadap motivasi berprestasi mahasiswa. Tujuan penelitian ini adalah untuk mengidentifikasi variabel-variabel yang terlibat dalam penelitian. Variabel penelitian dibagi menjadi dua, yaitu variabel terikat (dependent variable), serta variabel bebas (independent variable). Variabel-variabel tersebut adalah faktor kualitas pelayanan $\left(\mathrm{X}_{1}\right)$, dan komitmen $\left(\mathrm{X}_{2}\right)$ sebagai variabel bebas. Variabel terikat adalah motivasi berprestasi (Y).

Motivasi berprestasi adalah sesuatu yang menimbulkan semangat dan merupakan suatu proses psikologis yang mencerminkan interaksi antara sikap, kebutuhan, persepsi, dan keputusan yang terjadi pada diri seseorang. Motivasi timbul akibat faktor dalam diri seseorang yang disebut faktor intrinsik dan dari luar diri seseorang yang disebut faktor ekstrinsik. Robbins (1996:205) mengemukakan bahwa prestasi, kekuasaan dan afiliasi merupakan tiga kebutuhan penting yang membantu memahami motivasi. Kebutuhan seseorang akan prestasi antara lain tercermin dari keinginan mengambil tugas yang dapat dipertanggung jawabkan dan menentukan tujuan yang wajar dengan memperhitungkan resiko-resikonya. Kebutuhan tentang kekuasaan antara lain tercermin dari seseorang yang ingin memunyai pengaruh atas orang lain di sekitarnya dan membuat terkesan padanya. Kebutuhan tentang afiliasi antara lain ditunjukkan 
adanya keinginan untuk bersahabat dan lebih senang bekerja bersama.

Definisi motivasi menurut Osborn (2007) adalah nilai dan kepercayaan yang ada pada diri seseorang, yang dapat menentukan perilaku mereka dalam menjalankan tugas yang dipercayakan kepadanya. Motivasi menurut Woolfolk (1995:123) adalah a high level of task commitment or motivation to achieve in certain areas. Motivasi seseorang terhadap tugas diartikan sesuai dengan konsep di atas adalah suatu dorongan khusus untuk mencapai tujuan. Hanya mereka yang memiliki dorongan dan tanggung jawab tinggi yang akan menunjukkan prestasi yang baik dan memiliki nilai lebih. Motivasi berprestasi merupakan motivasi yang mendorong individu untuk sukses dan bertujuan untuk berhasil dalam kompetisi dengan beberapa ukuran keunggulan (Mulyana, 2013:490). Pendapat lain (Lanyon, 1997:77) menyebutkan motivasi berprestasi adalah the psychological need in human for success in school, work, and other areas of life. Dengan demikian, dapat disimpulkan motivasi berprestasi adalah kebutuhan, harapan dan nilai psikologis manusia untuk sukses dengan cara memenuhi tugas, bersaing dengan standar unggul, baik dalam pendidikan, pekerjaan maupun di area kehidupan secara luas.

Kualitas pelayanan antara lain dilihat dari sejumlah keistimewaan produk, yang memenuhi keinginan pelanggan, serta memberikan kepuasan pelanggan dalam penggunaan produk tersebut. Lovelock (1988:229) menyatakan bahwa kualitas adalah quality is degree of excellent intended, and the control of variability in achieving that excellent, in meeting the customer's requirements. Kualitas merupakan tingkat mutu yang diharapkan, dan dapat dikendalikan keragamannya dalam mencapai mutu untuk memenuhi kebutuhan pelanggan. Untuk dapat memberikan kualitas pelayanan yang baik, perlu dibina hubungan yang erat antara pengelola dan pemakai jasa pelayanan tersebut.

Zeithmal (1990:19) mengemukakan bahwa kualitas pelayanan dapat didefinisikan sebagai: "The extent of discrepancy between customers expectations or desire and their perceptions". Dari pernyataan tersebut, terlihat bahwa kualitas pelayanan yang diterima konsumen dinyatakan besarnya perbedaan antara harapan atau keinginan konsumen dengan tingkat persepsi mereka.

Komponen pelayanan dalam bisnis tidak dapat dipisahkan baik untuk perusahaan jasa maupun pendidikan. Jasa dihasilkan dan dikonsumsi secara bersamaan, tidak seperti barang fisik yang di produksi, kemudian baru di konsumsi. Kotler (2000:440) mengemukakan bahwa ada lima faktor dominan atau penentu kualitas pelayanan yang di singkat dengan TERRA yaitu: Pertama; Tangible (berwujud) berupa penampilan fisik, peralatan dan berbagai materi komunikasi yang baik, menarik, terawat dan lancar. Kedua; Empathy merupakan kesediaan karyawan untuk lebih peduli memberikan perhatian secara pribadi kepada pelanggan. Jika pelanggan mengeluh, harus dicari solusi segera, agar selalu terjaga hubungan harmomis dengan menunjukkan rasa peduli yang tulus. Ketiga; Responsiveness (cepat tanggap), kemauan dari karyawan untuk membantu pelanggan dan memberikan pelayanan dengan cepat serta mendengarkan dan mengatasi keluhannya. Keempat; Reliability (keandalan), kemampuan untuk memberikan pelayanan sesuai dengan yang dijanjikan, terpercaya, akurat dan konsisten. Kelima; Assurance (kepastian), berupa kemampuan karyawan untuk menimbulkan keyakinan dan kepercayaan terhadap janji yang telah di kemukakan kepada konsumen.

Berdasarkan beberapa definisi di atas dapat disimpulkan bahwa kualitas pelayanan termasuk kepada mahasiswa adalah perbandingan antara harapan terhadap pelayanan dengan pelayanan yang dirasakan oleh mahasiswa. Apabila pelayanan yang diberikan secara profesional, maka pelayanan akan berkualitas.

Variabel selanjutnya yang perlu didiskusikan dalam tulisan ini adalah komitmen. Individu berbakat cenderung memperlihatkan ciri memiliki komitmen yang kuat dan terpusat terhadap tugas-tugas yang dihadapinya. Salah satu keberbakatan adalah a high level of task commitment or motivation to achieve in certain areas (Woolfolk, 1995:123). Komitmen seseorang terhadap tugas diartikan sesuai dengan 
konsep di atas adalah suatu dorongan khusus untuk mencapai tujuan. Dalam hal tersebut mengindikasikan bahwa keberhasilan belajar tidak hanya tergantung pada faktor intelektual, tetapi juga komitmen dan motivasi belajar, yaitu dorongan untuk menyelesaikan tugas dan kewajiban belajar secara teratur dan berdisiplin.

Dengan demikian, faktor ini berhubungan dengan tanggung jawab dan disiplin pribadi untuk mengerjakan sesuatu yang telah menjadi komitmennya. Beberapa penelitian tentang komitmen berprestasi dianggap sebagai ciri yang berfungsi pendorong terjadinya proses aktualisasi bakat. Karena adanya komitmen terhadap tugas, mahasiswa mau belajar lebih tekun dan berdisiplin untuk meraih hasil belajar yang bermutu. Perbedaan antara orang yang sukses dengan yang tidak sukses bukanlah pada dimensi intelektual saja, tetapi termasuk juga komitmen memecahkan masalah. Hal ini ditekankan oleh Treffinger (1990:34) tentang keunikan kriteria bakat yang meliputi: "Curiosity, imagination, productivity, independence in thought and judgment, extensive fund of information and ideas, persistence, commitment to solving problems, concern with the future and the unknown, not merely with the past, the present, or the known".

Komitmen merupakan sesuatu yang menggerakkan (mengaktifkan) potensi yang ada pada diri, sebagai suatu persyaratan yang harus dipenuhi untuk dapat digolongkan sebagai seseorang yang memunyai keunggulan. Dengan demikian, komitmen adalah kecenderungan melibatkan diri kedalam apa yang dikerjakan dengan keyakinan bahwa kegiatan yang dikerjakan penting dan berarti. Komitmen terhadap tugas terjadi bila terdapat keyakinan yang kuat untuk menyelesaikannya dan tugas tersebut dianggap penting untuk mendapatkan prestasi. Di samping itu, komitmen dapat dianggap sebagai penyusunan energi khusus yang terpusat pada usaha belajar dan menyelesaikan tugas dengan baik serta dorongan untuk berprestasi. Dengan demikian, semua perilaku, termotivasi untuk mereduksi rangsangan yang menimbulkan eksitasi (excitation) pada sistem. Kecenderungan melibatkan diri sebagai rangsangan apabila ditinjau dari asal atau sumber untuk bertindak, bisa datang dari dalam diri seseorang berupa, sikap, pengalaman, pendidikan, harapan, cita-cita yang ingin diraih. Rangsangan juga bisa berasal dari faktor luar diri seseorang, misalnya karena pengaruh pimpinan, teman dan faktor lainnya. Karena salah satu sumber komitmen, is direct experience with an attitude object.

Secara umum orang memunyai tujuan untuk berhasil, mengejar prestasi, penghargaanpenghargaan dan imbalan keberhasilan. Mereka memunyai hasrat untuk melakukan sesuatu secara lebih baik atau lebih efisien daripada yang dilakukan sebelumnya. Dari riset mengenai kebutuhan berprestasi, ditemukan bahwa orangorang yang berprestasi tinggi membedakan diri mereka dengan orang-orang lain, berkat kehendak mereka untuk melakukan segala sesuatu dengan cara lebih baik. Berdasarkan beberapa hasil penelitian dapat dibuat beberapa ramalan tentang hubungan antara kebutuhan akan prestasi. Meskipun dilakukan dengan penelitian yang sederhana terhadap kebutuhan, ternyata terdapat temuan-temuan yang konsisten.

Pertama, individu-individu dengan kebutuhan berprestasi yang tinggi lebih menyukai situasi kerja dengan tanggung jawab pribadi, umpan balik, dan tingkat resiko yang sedang. Apabila ciri-ciri ini menonjol, orang-orang yang tinggi kebutuhan prestasinya akan memunyai komitmen yang kuat. Kedua, suatu kebutuhan yang tinggi untuk berprestasi tidaklah dengan sendirinya menuntun ke arah menjadi memunyai prestasi yang tinggi. Komitmen berprestasi dapat juga dikatakan sebagai suatu persetujuan diri untuk mencapai sesuatu, karena ada kekuatan yang mendorong timbul dari dalam maupun dari luar diri pribadi seseorang. Kekuatan tersebut dapat berbentuk rangsanganrangsangan positif maupun negatif yang kemudian membentuk suatu reaksi dalam bentuk komitmen untuk berbuat.

Dari berbagai teori di atas tentang kualitas pelayanan, komitmen, dan motivasi berprestasi, akan disampaikan kerangka pemikiran bagaimana variabel-variabel tersebut berhubungan dan saling memengaruhi. Kurtz (1998: 
382) menyatakan bahwa pelayanan yang diberikan kepada pelanggan sesuai dengan yang diharapkan, akan memberikan kepuasan. Kepuasan terhadap pelayanan tentu akan menimbulkan semangat untuk berbuat yang lebih baik (prestasi). Sikap dan komitmen terhadap pekerjaan merupakan tendensi yang tetap tentang perasaan dan perilaku terhadap suatu objek atau pekerjaan tersebut (Spector, 2006:381). Hal ini dapat dianggap bahwa para mahasiswa yang menunjukkan sikap positif terhadap tugasnya akan melaksanakan pekerjaan dengan lebih baik. McClelland (1987) berpendapat bahwa ada hubungan yang positif antara motivasi berprestasi dengan pencapaian prestasi. Sementara itu, menurut Long (2000:219), komitmen merupakan ikrar atau ikatan terhadap sesuatu tindakan. Dorongan internal akan mengarahkan suatu kemampuan untuk keberhasilan belajar.

\section{Kerangka Konseptual}

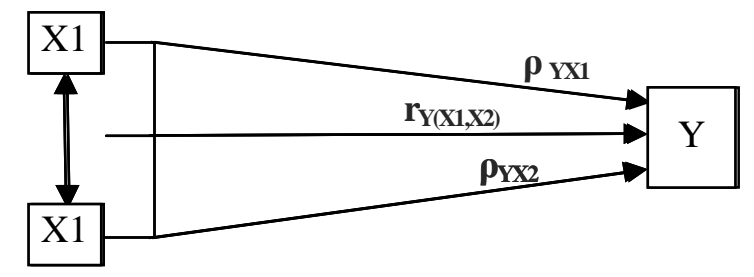

\section{Gambar 1. Kerangka Konseptual}

Untuk kepentingan penelitian, hubungan antara variabel terikat dan variabel bebas, disimbolkan $\mathrm{X}_{1}$ (kualitas pelayanan) dan $\mathrm{X}_{2}$ (komitmen) sebagai variabel bebas, sedangkan $\mathrm{Y}$ (motivasi berprestasi) sebagai variabel terikat.

\section{METODE}

Penelitian ini mengambil referensi kepada metode penelitian sosial dengan berbagai variasi analisis yang pernah dilakukan sebelumnya (Rosete dan Ciarrochi, 2005). Metode yang digunakan dalam penelitian ini adalah correlation analysis yang bertujuan untuk mengetahui sejauh mana variasi-variasi pada suatu faktor berkaitan dengan variasi pada suatu atau lebih faktor lain berdasarkan koefisien korelasi. Untuk melihat pengaruh di antara variabel akan digunakan juga Path Analysis dengan menghitung koefisien jalur. Penelitian dilakukan me- lalui survei, karena ingin mengungkap keadaan nyata tentang hal-hal yang dialami sampel penelitian, untuk menguji hipotesis tentang seberapa besar pengaruh kualitas pelayanan dan komitmen terhadap motivasi berprestasi.

Penelitian ini dilakukan di PTS Jakarta dengan sasaran penelitian mahasiswa sebagai populasi. Karena jumlah mahasiswa cukup besar dan terbatasnya sumber daya penelitian, penelitian hanya dilakukan untuk 80 orang. Dipilih sampel secara acak sederhana (simple random sampling) dari beberapa PTS, sehingga diperoleh 20 orang untuk uji coba instrumen penelitian dan 60 orang sebagai sampel penelitian.

Penelitian ini menggunakan data primer yang dikumpulkan melalui survei dengan instrumen penelitian berbentuk angket. Pengukuran dilakukan pada situasi nyata yang dilihat menurut penilaian responden tentang apa yang dialami, bukan apa yang diinginkan. Instrumen pengumpulan data, disusun dalam bentuk skala sikap metode likert. Skala sikap metode likert terdiri dari pernyataan-pernyataan (statements) yang disusun menyerupai tes objektif pilihan ganda. Alternatif jawaban yang disediakan dalam instrumen, dipilih jawaban dengan lima alternatif. Jawaban yang dipilih diharapkan dapat menggambarkan seberapa tinggi perasaan (affect) dan penilaian dari responden terhadap pernyataan yang disajikan dalam skala. Karena penilaian seseorang bisa "favorable" atau "unfavorable" terhadap sesuatu, maka pernyataan yang terdapat dalam skala disusun untuk menampung kedua sikap tersebut. Angket terdiri atas 3 bagian sesuai dengan jumlah variabel penelitian. Tiap-tiap variabel terdiri atas beberapa dimensi dan indikator, sebagai acuan dalam mengembangkan instrumen. Setiap butir angket berisi pernyataan-pernyataan yang ada kaitannya dengan faktor-faktor dari setiap variabel.

Sebelum instrumen penelitian digunakan, terlebih dahulu diadakan kalibrasi dan uji coba instrumen. Penyempurnaan instrumen dilakukan pada tahap awal sebagai uji validitas content, melalui diskusi instrumen penelitian. Hasil diskusi telah dapat memperbaiki pernyataanpernyataan dalam skala sehingga mewakili 
sample of bahavior to be measured (Anastasi, 1997:102), dan sudah cukup relevan serta representatif. Uji coba instrumen sebagai uji empiris dilakukan pada 20 orang responden mahasiswa PTS Jakarta. Maksud ujicoba instrumen adalah untuk menguji kehandalan (validitas) dan kesahihan (reliabilitas) butir-butir yang akan digunakan dalam penelitian.

Prosedur analisis tersebut sekaligus memberikan gambaran tentang internal consistency yang didasarkan pada homogenitas butir, serta memunyai relevansi dengan content validity instrumen. Instrumen yang diujicoba, dianalisis dengan tujuan untuk menyeleksi butir-butir yang valid, handal dan komunikatif, melalui teknik korelasi product moment antara skor masing-masing butir dengan skor totalnya. Koefisien reliabilitas instrumen digunakan untuk melihat konsistensi jawaban yang diberikan responden, dengan menggunakan alpha cronbach (Azwar, 1997:5). Metode ini dipilih dan dianggap sesuai karena instrumen disusun untuk menggali pengalaman maupun penilaian responden sehingga seluruh butir dianggap mengukur konsep yang sama. Dari hasil pengujian kehandalan dan kesahihan butir-butir instrumen, di peroleh beberapa butir yang koefisien validitasnya signifikan (alpha $=0,05$, $r>0,444)$. Untuk variabel motivasi berprestasi diperoleh 29 butir, dengan reliabilitas sebesar 0,651 , variabel kualitas pelayanan diperoleh 25 butir dengan reliabilitas sebesar 0,577 , variabel komitmen diperoleh 26 butir dengan reliabilitas sebesar 0,757 .

Selanjutnya, dilakukan analisis data untuk mengetahui hubungan antara variabel $\mathrm{X}_{1}$ dan $\mathrm{X}_{2}$ sebagai variabel bebas dengan variabel Y sebagai variabel terikat, melalui perhitungan koefisien korelasi. Analisis koefisien determinasi merupakan suatu analisis untuk mengetahui konstribusi pengaruh variabel bebas terhadap variabel terikat secara persentase. Tinggi rendahnya tingkat keeratan hubungan antar variabel penelitian dapat dilihat dari besar kecilnya nilai koefisien korelasi (r) yang diperoleh dari hasil analisis data penelitian dengan meng- gunakan software SPSS 17.0. Analisis regresi untuk melihat hubungan fungsional antara variabel bebas dengan variabel terikat, yang disimbulkan dengan $Y=f(X)$, di mana perubahan rata-rata harga $\mathrm{Y}$ ditentukan oleh turun naiknya harga setiap unit X. Analisis jalur untuk menganalisis pola hubungan kausal beberapa variabel penyebab terhadap variabel akibat.

\section{HASIL DAN PEMBAHASAN \\ Hasil}

Sebelum dilakukan analisis data, dilakukan pengujian persyaratan analisis untuk membuktikan apakah data berdistribusi normal dan homogen. Untuk mengetahui apakah data yang akan dianalisis berdistribusi normal, digunakan uji Lilliefors, yang meliputi pengujian normalitas variabel kualitas pelayanan $\left(\mathrm{X}_{1}\right)$, komitmen $\left(\mathrm{X}_{2}\right)$, dan motivasi berprestasi $(\mathrm{Y})$. Dengan menggunakan taraf signifikan $\alpha=0,05$ dan banyaknya $n=60$, didapat hasil seperti tabel berikut.

\section{Tabel 1. Uji Normalitas}

\begin{tabular}{lcll}
\hline & \multicolumn{3}{c}{ Kolmogorov-Smirnov ${ }^{\mathrm{a}}$} \\
\cline { 2 - 4 } & Statistic & df & Sig. \\
\hline Layanan & .072 & 60 & $.200^{*}$ \\
Komitmen & .093 & 60 & $.200^{*}$ \\
Prestasi & .111 & 60 & .063 \\
\hline
\end{tabular}

a. Lilliefors Significance Correction

*. This is a lower bound of the true significance.

Seluruh variabel dengan $\alpha=0,05$ diperoleh $\mathrm{L}_{\text {0bservasi }}<\mathrm{L}_{\text {tabel }}$, (untuk $\mathrm{n}=60$, nilai kritis 0,114: Sudjana, 2005:467), walaupun variabel motivasi berprestasi tidak terlalu signifikan, nilai statistik tetap dibawah nilai kritis. Dengan demikian, hasil pengujian menunjukkan sampel yang dipilih berasal dari populasi yang berdistribusi normal. Selanjutnya, pengujian homogenitas varians, kelompok data $\mathrm{Y}$ didasarkan pada urutan data $\mathrm{X}_{1}$ dan $\mathrm{X}_{2}$ dengan uji Bartlett. 
Tabel 2. Hasil Pengujian Homogenitas Varians Populasi

\begin{tabular}{lccccccc}
\hline $\begin{array}{c}\text { Kelompok } \\
\text { Sampel }\end{array}$ & Jumlah Sampel & $\begin{array}{c}\text { Jumlah } \\
\text { Kelompok }\end{array}$ & $\mathrm{Dk}$ & $\mathrm{X}_{\text {hitung }}^{2}$ & $\begin{array}{c}\mathrm{X}_{\text {tabel }}^{2} \\
0,05\end{array}$ & $\begin{array}{c}\alpha= \\
\mathrm{X}_{1}\end{array}$ \\
$\mathrm{X}_{2}$ & 60 & 17 & 16 & 16,79 & 26,3 & Kesimpulan \\
\hline
\end{tabular}

Tabel 3. Analisis Varians Regresi $Y$ atas $X_{1}$

\begin{tabular}{ccccccc}
\hline & Model & Sum of Squares & Df & Mean Square & F & Sig. \\
\hline 1 & Regression & 388.077 & 1 & 388.077 & 15.179 & $.000^{\mathrm{a}}$ \\
& Residual & 1482.857 & 58 & 25.566 & & \\
& Total & 1870.933 & 59 & & & \\
\hline
\end{tabular}

a. Predictors: (Constant), Layanan

b. Dependent Variable: Prestasi

Tabel 4. Perhitungan Persamaan Regresi

\begin{tabular}{|c|c|c|c|c|c|c|}
\hline & \multirow[b]{2}{*}{ Model } & \multicolumn{2}{|c|}{$\begin{array}{l}\text { Unstandardized } \\
\text { Coefficients }\end{array}$} & \multirow{2}{*}{$\begin{array}{c}\begin{array}{r}\text { Standardized } \\
\text { Coefficients }\end{array} \\
\text { Beta }\end{array}$} & \multirow[b]{2}{*}{$\mathrm{t}$} & \multirow[b]{2}{*}{ Sig. } \\
\hline & & B & Std. Error & & & \\
\hline \multirow[t]{2}{*}{1} & (Constant) & 92.154 & 6.700 & & 13.754 & .000 \\
\hline & Layanan & .246 & .063 & .455 & 3.896 & .000 \\
\hline
\end{tabular}

a. Dependent Variable: Prestasi

Harga setiap $X_{\text {hitung }}^{2}$ lebih kecil dari harga $X_{\text {tabel, }}^{2}$ artinya varians kelompok-kelompok $\mathrm{X}_{1}$ dan $\mathrm{X}_{2}$ terhadap $\mathrm{Y}$ adalah homogen.

Analisis data diawali dengan analisis regresi dan korelasi. Dari hasil analisis regresi sederhana $\mathrm{Y}$ atas $\mathrm{X}_{1}$ diperoleh persamaan regresi $\hat{Y}=92,15+0,246 X_{1}$. Secara keseluruhan, pengujian signifikansi hubungan antara kualitas pelayanan terhadap motivasi berprestasi, digambarkan dalam Tabel 3.

Berdasarkan hasil uji yang dilakukan, terbukti bahwa uji regresi $F_{\text {hitung }}=15,179$ lebih besar dari $\mathrm{F}_{\text {tabel }(1 / 58: 0,05)}=1,0$, berarti regresi $\hat{Y}=$ $92,15+0,246 X_{1}$ sangat signifikan. Hasil perhitungan diperoleh koefisien korelasi $r=0,455$, dan koefisien determinasi $r^{2}=0,207$. Koefisien korelasi ini ternyata sangat signifikan setelah uji $\mathrm{t}\left(\mathrm{t}_{\text {hitung }}=3,896>\mathrm{t}_{\text {tabel( } \mathrm{n}=60: 0,05)}=1,67\right)$, sehingga dapat disimpulkan terdapat hubungan positif antara kualitas pelayanan dengan motivasi berprestasi.

Dengan koefisien determinasi seperti pada Tabel 5 , berarti $20,7 \%$ variasi yang terjadi dalam tinggi rendahnya motivasi berprestasi disumbangkan oleh kualitas pelayanan, selebihnya oleh variabel lain. Hasil pengujian ini menunjukkan bahwa keeratan hubungan kualitas pelayanan terhadap motivasi berprestasi di lingkungan PTS Jakarta cukup berarti.

Hasil pengujian regresi sederhana $\mathrm{Y}$ atas $\mathrm{X}_{2}$ diperoleh persamaan regresi $\hat{\mathrm{Y}}=$ $90,27+0,249 X_{2}$. Secara keseluruhan, pengujian signifikansi hubungan antara komitmen terhadap motivasi berprestasi, digambarkan dalam Tabel 6. 
Berdasarkan penghitungan yang dilakukan, terbukti bahwa uji regresi $F_{\text {hitung }}=8,550$ lebih besar dari $\mathrm{F}_{\text {tabel(1/58:0,05) }}=1,0$, yang berarti regresi $\hat{Y}=90,27+0,249 \mathrm{X}_{2}$ sangat signifikan.

Hasil perhitungan koefisien korelasi $(\mathrm{r})=$ 0,358 , dan koefisien determinasi $\left(\mathrm{r}^{2}\right)=0,128$, sangat signifikan melalui uji $\mathrm{t}\left(\mathrm{t}_{\text {hitung }}=2,924>\right.$ $\left.\mathrm{t}_{\text {tabel }(\mathrm{n}=60: 0,05)}=1,67\right)$, sehingga dapat disimpulkan bahwa terdapat hubungan positif antara komitmen dengan motivasi berprestasi.

\section{Tabel 5. Perhitungan Koefisien Korelasi}

\begin{tabular}{|c|c|c|c|c|c|c|c|c|c|c|}
\hline \multirow[b]{2}{*}{ Model } & \multirow[b]{2}{*}{$\mathrm{R}$} & \multirow[b]{2}{*}{$\begin{array}{c}\mathrm{R} \\
\text { Square }\end{array}$} & \multirow[b]{2}{*}{$\begin{array}{c}\text { Adjusted R } \\
\text { Square }\end{array}$} & \multirow[b]{2}{*}{$\begin{array}{l}\text { Std. Error of the } \\
\text { Estimate }\end{array}$} & \multicolumn{5}{|c|}{ Change Statistics } & \multirow[b]{2}{*}{$\begin{array}{l}\text { Durbin- } \\
\text { Watson }\end{array}$} \\
\hline & & & & & $\begin{array}{c}\text { R Square } \\
\text { Change }\end{array}$ & F Change & df1 & df 2 & $\begin{array}{l}\text { Sig. F } \\
\text { Change }\end{array}$ & \\
\hline 1 & $.455^{\mathrm{a}}$ & 207 & 194 & 5.056 & .207 & 15.179 & & 58 & .000 & 1.017 \\
\hline
\end{tabular}

a. Predictors: (Constant), Layanan

b. Dependent Variable: Prestasi

Tabel 6. Analisis Varians Regresi $Y$ atas $X_{2}$

\begin{tabular}{ccccccc}
\hline & Model & Sum of Squares & Df & Mean Square & F & Sig. \\
\hline 1 & Regression & 240.378 & 1 & 240.378 & 8.550 & $.005^{\mathrm{a}}$ \\
& Residual & 1630.555 & 58 & 28.113 & & \\
& Total & 1870.933 & 59 & & & \\
\hline
\end{tabular}

a. Predictors: (Constant), Komitmen

b. Dependent Variable: Prestasi

\section{Tabel 7. Perhitungan Persamaan Regresi}

\begin{tabular}{|c|c|c|c|c|c|c|}
\hline \multirow[b]{2}{*}{ Model } & & \multicolumn{2}{|c|}{ Unstandardized Coefficient } & \multirow{2}{*}{$\begin{array}{l}\text { Standardized } \\
\text { Coefficients } \\
\text { Beta }\end{array}$} & \multirow[b]{2}{*}{$\mathrm{t}$} & \multirow[b]{2}{*}{ Sig. } \\
\hline & & B & Std. Error & & & \\
\hline \multirow[t]{2}{*}{1} & (Constant) & 90.276 & 9.551 & & 9.452 & .000 \\
\hline & Komitmen & .249 & .085 & .358 & 2.924 & .005 \\
\hline
\end{tabular}

a. Dependent Variable: Prestasi

Tabel 8. Perhitungan Koefisien Korelasi

\begin{tabular}{|c|c|c|c|c|c|c|c|c|}
\hline \multirow[b]{2}{*}{ Model } & \multirow[b]{2}{*}{$\mathrm{R}$} & \multirow[b]{2}{*}{$\begin{array}{c}\mathrm{R} \\
\text { Square }\end{array}$} & \multirow[b]{2}{*}{$\begin{array}{l}\text { Adjusted R } \\
\text { Square }\end{array}$} & \multirow[b]{2}{*}{$\begin{array}{l}\text { Std. Error of the } \\
\text { Estimate }\end{array}$} & \multicolumn{3}{|c|}{ Change Statistics } & \multirow[b]{2}{*}{$\begin{array}{l}\text { Durbin- } \\
\text { Watson }\end{array}$} \\
\hline & & & & & $\begin{array}{l}\text { R Square } \\
\text { Change }\end{array}$ & F Change df1 df2 & $\begin{array}{l}\text { Sig. F } \\
\text { Change }\end{array}$ & \\
\hline$\overline{1}$ & $.358^{\mathrm{a}}$ & .128 & .113 & 5.302 & .128 & $\begin{array}{lll}8.550 & 1 & 58\end{array}$ & .000 & 1.090 \\
\hline
\end{tabular}

a. Predictors: (Constant), Komitmen

b. Dependent Variable: Prestasi 
Tabel 9. Analisis Varians Regresi $Y$ atas $X_{1}$ dan $X_{2}$

\begin{tabular}{ccccccc}
\hline & Model & Sum of Squares & Df & Mean Square & F & Sig. \\
\hline 1 & Regression & 476.505 & 2 & 238.253 & 9.739 & $.000^{\mathrm{a}}$ \\
& Residual & 1394.428 & 57 & 24.464 & & \\
Total & 1870.933 & 59 & & & \\
\hline
\end{tabular}

a. Predictors: (Constant), Layanan, Komitmen

b. Dependent Variable: Prestasi

Tabel 10. Perhitungan Persamaan Regresi

\begin{tabular}{|c|c|c|c|c|c|}
\hline & \multirow[b]{2}{*}{ Model } & \multicolumn{4}{|c|}{ Standardized } \\
\hline & & B & Std. Error & $\frac{\text { Coefficients }}{\text { Beta }}$ & $\mathrm{t}$ \\
\hline \multirow[t]{3}{*}{1} & (Constant) & 78.653 & 9.663 & & 8.139 \\
\hline & Layanan & .204 & .066 & .377 & 3.107 \\
\hline & Komitmen & .160 & .084 & .231 & 1.901 \\
\hline
\end{tabular}

a. Dependent Variable: Prestasi

Tabel 11. Perhitungan Koefisien Korelasi

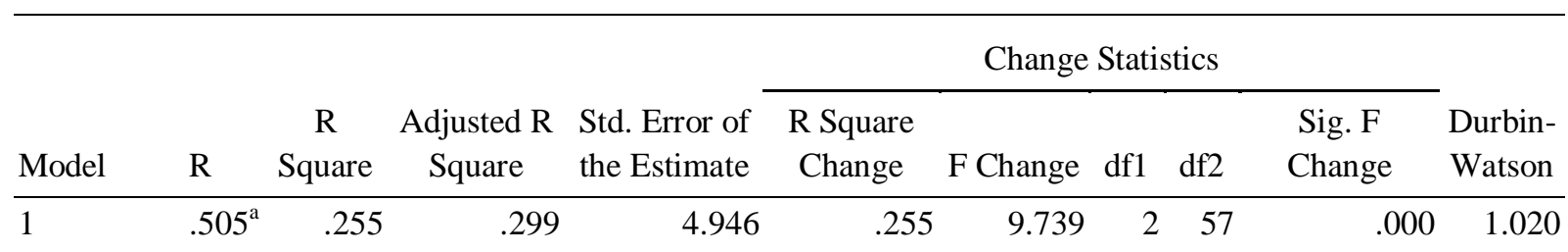

a. Predictors: (Constant), Layanan, Komitmen

b. Dependent Variable: Prestasi

Dengan koefisien determinasi di atas, dapat disimpulkan bahwa $12,8 \%$ variasi yang terjadi dalam meningkatnya motivasi berprestasi disumbangkan oleh variabel komitmen, selebihnya oleh variabel lain. Hasil pengujian ini menunjukkan bahwa keeratan hubungan komitmen terhadap motivasi berprestasi dapat dibuktikan berdasarkan hasil penelitian.

Analisis regresi linear jamak motivasi berprestasi $(\mathrm{Y})$ terhadap kualitas pelayanan $\left(\mathrm{X}_{1}\right)$ dan komitmen $\left(\mathrm{X}_{2}\right)$, menghasilkan persamaan regresi $\hat{\mathrm{Y}}=78,65+0,20 \mathrm{X}_{1}+0,16$ $\mathrm{X}_{2}$. Hasil pengujian signifikansi hubungan antara kualitas pelayanan dan komitmen terhadap motivasi berprestasi, digambarkan dalam Tabel 9.
Dari uji regresi, $F_{\text {hitung }}=9,739$ lebih besar dari $\mathrm{F}_{\text {tabel(2/57:0,05) }}=3,17$, berarti model regresi $\hat{\mathrm{Y}}$ $=78,65+0,20 X_{1}+0,16 X_{2}$ sangat signifikan. Hal ini juga mengandung arti, bahwa perubahan rata-rata $\mathrm{Y}$ sebesar 0,20 untuk setiap perubahan satu satuan $X_{1}$, apabila $X_{2}$ dianggap tetap, serta sebesar 0,16 untuk setiap perubahan satu satuan $X_{2}$, apabila $X_{1}$ dianggap tetap. Harga $r=0,505$ yang juga sangat signifikan, mengindikasikan terdapat hubungan positif antara kualitas pelayanan dan komitmen secara simultan dengan motivasi berprestasi. Artinya, semakin baik kualitas pelayanan dan semakin tinggi komitmen belajar akan semakin tinggi motivasi berprestasi. 
$\left[\begin{array}{c}\rho_{\mathrm{YX} 1} \\ \rho_{\mathrm{YX} 2}\end{array}\right]=\breve{\mathrm{R}}^{-1}\left[\begin{array}{c}\mathrm{r}_{\mathrm{YX} 1} \\ \\ \mathrm{r}_{\mathrm{YX} 2}\end{array}\right]$, dimana $\check{\mathrm{R}}=\left[\begin{array}{cc}1 & \mathrm{r}_{\mathrm{X} 1 \mathrm{X} 2} \\ & \\ & \\ \mathrm{r}_{\mathrm{X} X \mathrm{X} 1} & 1\end{array}\right], \quad \rho_{\mathrm{Y}(\mathrm{X} 1, \mathrm{X} 2)}=\mathrm{R}_{\mathrm{Y}(\mathrm{X} 1 \mathrm{X} 2)}^{2}, \rho_{\mathrm{YE}}=\sqrt{ }\left(1-\mathrm{R}^{2}\right)$

\section{Gambar 2. Rumus Menghitung Koefisien Jalur}

Dengan koefisien determinasi $\mathrm{r}^{2}=$ 0,255 , dapat disimpulkan bahwa $25,5 \%$ variasi yang terjadi dalam meningkatnya motivasi berprestasi ditentukan oleh kualitas pelayanan dan komitmen, sisanya oleh variabel lain. Dari hasil pengujian tersebut dapat disimpulkan bahwa secara bersama-sama antara kualitas pelayanan dan komitmen memiliki pengaruh terhadap motivasi berprestasi.

Selanjutnya, untuk melihat pengaruh langsung dan tidak langsung akan dilakukan melalui analisis jalur. Untuk melihat pengaruh variabel eksogen $\left(\mathrm{X}_{1}\right.$ dan $\left.\mathrm{X}_{2}\right)$ terhadap variabel endogen (Y), digunakan nilai koefisien jalur (path coefficient), yang disimbulkan dengan $\boldsymbol{\rho}_{\mathbf{Y X} \mathbf{1}}, \boldsymbol{\rho}_{\mathbf{Y X} \mathbf{2}}$, dan $\boldsymbol{\rho}_{\mathbf{Y}(\mathbf{X} \mathbf{1}, \mathbf{X} \mathbf{2})}$. Hubungan $\mathrm{X}_{1}$ dan $\mathrm{X}_{2}$ merupakan hubungan korelasional, dengan koefisien korelasi $\mathrm{r}_{\mathrm{X} 1 \mathrm{X} 2}$. Koefisien jalur $\left(\boldsymbol{\rho}_{\mathrm{Y \varepsilon}}\right)$ menggambarkan besarnya pengaruh langsung variabel residu (implicit exogenous variable) terhadap Y. Untuk menghitung koefisien jalur digunakan rumus seperti pada Gambar 2.

Dengan menggunakan SPSS, diperoleh $\rho_{\mathrm{YX} 1}=0,377, \rho_{\mathrm{YX} 2}=0,231, \rho_{\mathrm{Y}(\mathrm{X} 1 \mathrm{X} 2)}=0,255$ (Tabel 10 Beta, dan Tabel $11 \mathrm{R}$ Square), $\rho_{\mathrm{Y \varepsilon}}=$ 0,863 dan $r_{X 1 X 2}=0,388$. Semua koefisien jalur signifikan melalui uji $\mathrm{t}\left(\mathrm{t}_{\text {hitung }}>1,67\right.$, tabel 10$)$. Dari hasil tersebut diperoleh persamaan struktur analisis jalur: $\mathrm{Y}=0,377 \mathrm{X}_{1}+0,231 \mathrm{X}_{2}+0,863$. Pengaruh (langsung + tidak langsung) kualitas pelayanan terhadap motivasi berprestasi adalah $17,15 \%\left(\left(\left(\rho_{\mathrm{YX} 1}\right)^{2}+\left(\rho_{\mathrm{YX} 1} \mathrm{x} \mathrm{r}_{\mathrm{X} 1 \mathrm{X} 2} \mathrm{x} \rho_{\mathrm{YX} 2}\right)\right) \mathrm{x}\right.$ $100 \%)$. Pengaruh (langsung + tidak langsung) komitmen terhadap motivasi berprestasi adalah $8,27 \%\left(\left(\left(\rho_{\mathrm{YX} 2}\right)^{2}+\left(\rho_{\mathrm{YX} 1} \times \mathrm{r}_{\mathrm{X} 1 \mathrm{X} 2} \mathrm{x} \rho_{\mathrm{YX} 2}\right)\right) \times 100 \%\right.$ ) . Pengaruh kualitas pelayanan dan komitmen secara bersama-sama terhadap motivasi berprestasi adalah $25,5 \%\left(\rho_{\mathrm{Y}(\mathrm{X} 1 \mathrm{X} 2)} \times 100 \%\right)$.

\section{Pembahasan}

Berdasarkan hasil pengujian pertama, menggambarkan bahwa terdapat hubungan positif antara kualitas pelayanan dengan motivasi berprestasi mahasiswa. Pengujian ini menunjukkan bahwa keeratan hubungan antara kualitas pelayanan dengan motivasi berprestasi dibuktikan berdasarkah hasil penelitian, baik melalui analisis korelasi maupun analisis jalur. Dengan demikian, kualitas pelayanan berpengaruh terhadap motivasi berprestasi cukup berarti. Melihat besarnya koefisien determinasi kualitas pelayanan di atas terhadap motivasi berprestasi, dapat disimpulkan bahwa sumbangan yang disebabkan oleh kualitas pelayanan sebesar $20,7 \%$, selebihnya merupakan sumbangan variabel lain. Penemuan ini sejalan dengan pendapat Kurtz (1998:382), pelayanan yang diberikan kepada pelanggan sesuai dengan yang diharapkan, akan memberikan kepuasan. Kepuasan terhadap pelayanan tentu akan menimbulkan semangat untuk berbuat yang lebih baik (prestasi).

Dengan demikian, kualitas pelayanan harus dapat mendukung kenyamanan dan kesenangan mahasiswa sehingga mereka dapat melaksanakan tugas dan kewajibannya. Perguruan Tinggi dan pengelolaannya, bukanlah hanya sekedar tempat orang belajar, akan tetapi jauh lebih luas, karena menyangkut semua aspek-aspek yang memengaruhi efisiensi, efektifitas dan produktivitas belajar. Kualitas pelayanan yang baik akan menjadi pendorong bagi kegairahan dan efisiensi belajar dan pada gilirannya mendorong produktivitas belajar. Hubungan yang kurang serasi antara seorang pekerja pelayanan dengan mahasiswa, prosedur dan tata kerja yang tidak jelas menyebabkan kinerja yang buruk (Hadiana, 1996:50). Dari uraian di atas dapat disimpulkan bahwa dengan kualitas 
pelayanan yang baik, motivasi berprestasi akan meningkat pula.

Hasil pengujian kedua menunjukkan terdapat hubungan positif antara komitmen mahasiswa dengan motivasi berprestasi. Dengan pengujian ini menunjukkan bahwa keeratan hubungan antara komitmen dengan kualitas pelayanan dapat dibuktikan berdasarkan hasil penelitian, atau dengan kata lain komitmen memiliki pengaruh terhadap meningkatnya motivasi berprestasi mahasiswa di PTS Jakarta yag cukup berarti. Hasil pengujian ini mengandung makna bahwa mahasiswa yang sangat terikat dengan komitmennya dalam mencapai suatu tujuan yang telah ditetapkan, mereka memunyai kekuatan dalam dirinya yang sekaligus meningkatkan motivasi berprestasi. Komitmen sebagai bentuk motivasi internal dapat mendorong seseorang untuk tekun dan ulet mengerjakan tugasnya, meskipun mengalami bermacam-macam hambatan dan rintangan.

Hal ini sesuai degan pendapat Semiawan (1997:91), yang menyatakan bahwa suatu komitmen yang dimiliki seseorang akan menyebabkan mereka bekerja sungguh-sungguh dan tekun agar memperoleh hasil yang baik. Komitmen berprestasi merupakan persetujuan diri untuk mencapai sesuatu, karena ada kekuatan yang mendorong timbul dari dalam maupun dari luar diri pribadi seseorang. Hal ini sesuai dengan salah satu teori, bahwa komitmen adalah persetujuan untuk menyelesaikan suatu tugas (Humphrey, 2000:3). Adanya kegiatan atau aktivitas yang terarah pada usaha pencapaian tujuan yang pada akhirnya akan merupakan komitmen pada diri seseorang. Dengan demikian, dapat disimpulkan bahwa bila komitmen mahasiswa kuat, maka motivasi berprestasi akan tinggi dan sebaliknya.

Pengujian terakhir terdapat hubungan positif antara kualitas pelayanan dan komitmen secara bersama-sama dengan motivasi berprestasi. Penemuan ini sejalan dengan pandangan bahwa motivasi berprestasi seseorang akan terbentuk oleh faktor dalam dirinya antara lain komitmennya dan faktor eksternal seperti kualitas pelayanan. Motivasi berprestasi mahasiswa PTS Jakarta menurut hasil penelitian ini, 25\% dipengaruhi oleh kualitas pelayanan universitas dan komitmen mereka melaksanakan tugas, sedangkan yang lainnya, dipengaruhi oleh faktor-faktor yang belum termasuk dalam penelitian ini. Diduga faktorfaktor tersebut adalah kualitas dosen, fasilitas yang tersedia dan lain-lain. Motivasi berprestasi merupakan keinginan seseorang untuk menyelesaikan suatu tugas yang sulit atau dorongan dalam mengatasi rintangan dan memelihara kualitas kerja yang tinggi, serta bersaing melalui usaha yang gigih untuk mendapatkan hasil yang lebih baik dari sebelumnya.

Hasil ini telah sejalan dengan pendapat Apruebo (2005:53) yang menyatakan "Achievement motivation as a desire for significant accomplishment for mastery of things, people, or ideas for attaining a higher standard". Motivasi berprestasi pada hakikatnya merupakan keinginan, hasrat, kemauan, dan pendorong untuk dapat unggul dalam menyelesaikan tugas. Motivasi berprestasi merupakan dorongan untuk berpacu dengan keunggulan, baik keunggulan diri sendiri, maupun keunggulan dari orang lain. Penelitian para ahli pada beberapa dekade terakhir menunjukkan para mahasiswa yang berhasil memperoleh nilai tinggi, ternyata selain cerdas terbukti memiliki motivasi berprestasi yang lebih. Motivasi berprestasi yang dimiliki merupakan modal bagi seseorang untuk sukses, karena kinerja seseorang secara khusus dipengaruhi oleh motivasi yang muncul untuk menyelesaikan tugasnya.

Dari analisis tersebut di atas dapat disimpulkan bahwa terdapat pengaruh kualitas pelayanan dan komitmen baik secara sendirisendiri maupun bersama-sama terhadap motivasi berprestasi mahasiswa PTS di Jakarta.

\section{PENUTUP}

Penelitian menyimpulkan bahwa terdapat pengaruh serta hubungan positif dan signifikan antara kualitas pelayanan dan komitmen, baik sendiri-sendiri maupun secara 
bersama-sama dengan motivasi berprestasi mahasiswa PTS Jakarta. Artinya, akan meningkat motivasi berprestasi dengan meningkatnya kualitas pelayanan dan komitmen. Dengan demikian, secara umum motivasi untuk berprestasi untuk mendapatkan output PTS yang berkualitas, dipengaruhi langsung secara positif oleh kualitas pelayanan dan komitmen mahasiswa. Kualitas pelayanan memengaruhi secara dominan terhadap motivasi berprestasi.

Beberapa implikasi dari hasil penelitian ini, sesuai dengan konsep pengaruh kualitas pelayanan dan komitmen, dalam upaya meningkatkan motivasi berprestasi, adalah sebagai berikut: Pertama, motivasi berprestasi mahasiswa dapat ditingkatkan dengan cara mengoptimalkan pelayanan PTS sesuai prosedur dan standar kerja, antara lain ISO 9001, 14001, serta OHSAS 18001. Kedua, dengan peningkatan komitmen mahasiswa akan menimbulkan dorongan seseorang untuk berprestasi secara optimal sehingga kualitas output PTS dapat dicapai. Ketiga, meningkatkan motivasi berprestasi dan rasa tanggung jawab terhadap keberhasilan karena dengan rasa tanggung jawab yang tinggi, seseorang akan selalu berusaha meningkatkan prestasinya. Untuk meningkatkan rasa tanggung jawab terhadap keberhasilan, perlu ditanamkan komitmen dan keterikatan terhadap keberhasilan.

\section{UCAPAN TERIMA KASIH}

Pada kesempatan yang berbahagia ini, penulis mengucapkan terima kasih dan penghargaan setinggi-tingginya kepada semua pihak, terutama kepada tim evaluasi dan pengelola Jurnal Cakrawala Pendidikan Universitas Negeri Yogyakarta, yang telah berkenan mempublikasikan artikel ini. Semoga TuhanYang Maha Kuasa membalasnya dan melindungi kita semua.

\section{DAFTAR PUSTAKA}

Anastasi, Anne dan Susana. 1997. Psychological Testing. New York: Prentice Hall, Inc.
Apruebo, A.R. 2005. Sport Psychology. Manila: Publishing House.

Azwar, Syaifudin. 1997. Reliabilitas dan Validitas. Yogyakarta: Pustaka Pelajar.

Hadiana. 1996. Bisnis dan Manajemen. Jakarta: Arcan.

Humphrey, S.E. 2007. "Integrating Motivational, Social, and Contextual Work Design Features: A Meta-Analytic Summary and Theoretical Extension of the Work Design Literature". Journal of Applied Psychology. 92, No. 5, hlm.1332-1356.

Kotler P. 2000. Marketing Management; Analysis, Planning, Implementation and Control. Prentice-Hall. Inc.

Kurtz Clow. 1998. Service Marketing. Will \& Sons Inc, USA.

Lanyon, R.I. and Leonard, D.G. 1997. Personality Assessment. New York: John Wiley \& Sons, Inc.

Likert, Rensis. 1967. The Human Organization: Its Management and Value. New York: McGraw-Hill Book Company.

Long, M.L. 2000. Consumption Values and Relationship: Sigmenting the Market for Frequensy Programs. Journal of Consumer Marketing, Vol. 17, (3).

Lovelock, C. \& Wright Lauren. 1999. Principles Service Marketing and Management. New Jersey: Pearson Education.

McClelland D.C. 1987. Human Motivation. New York: Press Syndicate of the University of Cambridge.

Mulyana, B. 2013. "Hubungan Konsep Diri, Komitmen, dan Motivasi Berprestasi dengan Prestasi Renang Gaya Bebas". 
Cakrawala Pendidikan, XXX(3), hlm. 488-498.

Osborn, W. 2008. Laverage Points: 11 Tips Membangkitkan Motivasi Karyawan. Jakarta: PT. Prestasi Pustakarya.

Robbins, S.P. and Mary Coulter. 1996. Management. New Jersey: Prentice Hall, Inc.

Rosete, D. dan Ciarrochi, J. 2005. Leadership Organizational Development. Wollongong Australia: University of Wollongong.

Santosa, B., Dari "Brain Drain" ke "Brain Gain”. Kompas 2-5-2014,(6).

Semiawan, Conny. 1997. Perspektif Pendidikan Anak Berbakat. Jakarta: PT. Gramedia Widiasarana.
Spector, P.E. 2006. Industrial and Organizational Psychology. New York: John Wiley.

Sudjana. 2005. Metoda Statistika. Bandung: Tarsito.

Treffinger D.J. 1980. Encouraging Creative Learning for the Gifted and Talented. Ventura California: Ventura County Superintendent of Schools Office.

UNDP. Human Development Report 2013.

Woolfolk, Anita E. 1995. Educational Psychology. Boston: Allyn \& Bacon.

Zeithmal, V.A.P. dan Berry, L.L.A. 1985. Conceptual Model of Service Quality and Its Implications for Future Research. Journal of Marketing, XV(1), pp.41-50. 